\title{
Does Corporate Social Responsibility Matter to Consumers in Indonesia?
}

\section{Introduction}

Corporate Social Responsibility (CSR) has received significant attention in recent years (Jones et al., 2009; Ramasamy et al., 2010). McKinsey (2010) reveals that $76 \%$ of executives believe that CSR positively affects long-term shareholder value and $55 \%$ of executives agree that CSR helps build a strong reputation. Tsoi (2010) suggests that companies should integrate CSR into their mainstream business strategies and operations worldwide, not only in the companies' countries of origin. With less and less confidence in big business, corporations are now under increasing pressure to give money to charities, help solve social problems, protect the environment, and do many more things (Mohr et al., 2001). Companies now understand that bad publicity about CSR, whether it is true or not, will damage consumers' perceptions of the company and its products (Dean, 2004; Marconi, 1997).

Nevertheless, in the last few years, most of the research on perceptions of CSR has been conducted in the context of developed countries. There is very limited research investigating the impact of CSR on consumer support in the developing countries, especially Indonesia, the fourth most populous nation in the world. Thus, the purpose of the present research is first to examine consumers' perceptions of CSR and second to explore the impact of CSR on consumers' support. The results will assist managers operating in developing countries, especially Indonesia. In 2012, Indonesia attracted $\$ 5.9$ billion in foreign direct investment (FDI), indicating that the South East Asia's biggest economy remains a favourite despite concerns about corruption. India, with an economy twice the size of Indonesia, only attracts $\$ 4.43$ billion in FDI. The current study makes several contributions. First, it replicates the findings of previous scholarship on consumers' perceptions of CSR by Maignan (2001), 
especially as it relates to Indonesia, about which there is a relative dearth of literature on CSR. Second, it provides some insights for multinationals operating in Indonesia, as recently, Indonesia was named as one of the top four countries to invest in over the next three years (Forbes, 2012).

\section{Literature Review and Hypotheses Development}

\section{Perceptions of CSR}

CSR has predominantly emerged in the last 50 years as a result of the increasing importance of companies' contributions toward society's well-being (Carroll, 1999). Yet, there is still no consensus on a definition of CSR; it means different things to different stakeholders (Campbell, 2007; Jamali, 2008; Jones et al., 2009; McWilliams et al., 2006). Some of the widely used definitions are "a company's commitment to minimizing or eliminating any harmful effects and maximizing its long-run beneficial impact of society" (Mohr et al., 2001, p. 47); “a commitment to improve community well-being through discretionary business practices and contributions of corporate resources" (Kotler and Lee, 2005, p.3); and "the social responsibility of business encompasses the economic, legal, ethical, and discretionary expectation that society has of organizations at a given point in time" (Carroll, 1979, p. 500). Carroll's definition is probably the most widely used in most research on CSR (Lindgreen et al., 2010; Maignan, 2001; Ramasamy et al., 2010; Turker, 2008). The pyramid model suggests that the various responsibilities of businesses start with economic responsibilities, followed by legal, ethical, and philanthropic responsibilities.

Most of the studies on perceptions of CSR have been conducted in the context of developed countries: Hong Kong and Singapore (Ramasamy et al., 2010); the United States, France, and the Netherlands (Maignan, 2001); and the United States (Becker-Olsen et al., 2006; Mohr and Webb, 2005), with few in developing countries such as China (Ramasamy 
and Yeung, 2008); India (Shergill, 2012); and Nigeria (Ameshi et al., 2006). The current global discourse of CSR emphasises its cultural universality and benefits (Kemp 2001; Quazi and O'Brien, 2000). Nonetheless, the few studies on CSR in the developing countries have produced mixed results (Arli and Lasmono, 2010). For example, a study of perceptions of CSR in Botswana and Malawi shows that there are no clear differences between Malawi and Botswana compared to CSR in the United States (Lindgreen et al., 2010). Another study in China suggests that Carroll's pyramid of responsibilities can be applied in China (Ramasamy and Yeung, 2008). In contrast, a study on CSR perceptions in Nigeria shows that CSR is still largely philanthropic and altruistic (Ameshi et al., 2006). CSR does not follow a linear progression (Carroll, 1991; 2004).

Lindgreen et al. (2010) argue that what constitutes CSR in the developed countries may well be of limited utility in other contexts. Visser (2006) suggests that more empirical studies are needed, since relative priorities of CSR in the developing countries are likely to be different from the developed countries. In many developing countries, the institutions, standards, and appeals systems are relatively weak compared to North America and Europe (Kemp, 2001). Culture will have an important influence on perceived CSR priorities (Burton et al., 2000; Pinkston and Carroll, 1994). An extensive study by Baskin (2006), which investigated the level of CSR activities of 127 leading companies from 21 emerging markets and compared them with companies in high-income OECD countries, revealed that there are minor differences between companies in the developed countries and their counterparts in the developing countries. However, CSR in the developing countries is less embedded in corporate strategies, less pervasive, and less politically rooted than in the developed countries. Thus, Visser (2008) proposes a modification of Carroll's classic pyramid. In the context of developing countries, after economic responsibilities, philanthropic responsibility is given the second highest priority, followed by legal and finally ethical responsibilities. 
Following the above findings on CSR classifications and previous research using Carroll's framework (Maignan, 2001), consumers in Indonesia are likely to differentiate between the four dimensions of CSR proposed, as suggested in the following hypothesis:

$\mathbf{H}_{1}$ : Consumers in Indonesia will distinguish between the following four types of corporate social responsibility: (a) economic, (b) legal, (c), ethical, and (d) philanthropic.

Furthermore, as suggested by Ameshi et al. (2006), in the context of developing countries, philanthropic responsibilities will be emphasised. Similarly, Visser (2008) argues that economic responsibilities will get the most emphasis. Nevertheless, philanthropic responsibilities will be given the second highest priority followed by legal and ethical responsibilities. Thus, this study proposes the following hypothesis:

$\mathbf{H}_{2}$ : $\quad$ Consumers in Indonesia will first allocate economic responsibilities, followed by (1) philanthropic responsibilities, (2) legal responsibilities, and (3) ethical responsibilities.

\section{Consumers' Support of CSR}

Stakeholder theory suggests that companies are responsible to various groups within society (Freeman, 1984) and one of the largest groups of stakeholders is consumers (Maignan, 2001). Various studies have shown that communications of CSR have a significant effect on consumer behaviour (Podnar and Golob, 2007). Decades of studies have revealed mixed results on how consumers respond to CSR (Margolis et al., 2008; Smith et al., 2010). A number of studies have found positive correlations between CSR and consumer behaviour; these studies have found that first, CSR will induce purchase intentions (Smith and Higgins 2000; Varadarajan and Menon, 1988). Commitment to CSR is important when buying products or services and consumers are willing to pay more for products or services that are socially or environmentally responsible (Creyer and Ross, 1997; Ramasamy and Yeung, 2008). Second, CSR can boost positive evaluations of and satisfaction with companies and their brands (Brown and Dacin, 1997; Dawkins and Lewis, 2003; Jones, 2005; McDonald and 
Rundle-Thiele, 2008; Sen and Bhattacharya, 2001) and third, it will effectively counter negative publicity (Coombs, 1995; Vanhamme and Grobben, 2009). In addition, CSR will affect not only regular consumers, but also industrial buyers who are influenced by intangible features such as trust, brand association, supplier reputation, and image (Cretu and Brodie, 2007; Fombrum et al., 2000; Lai et al., 2010; Mudambi, 2002).

In contrast, another group of studies reveal that first; CSR is not the primary concern when consumers are shopping (Bucic et al., 2012; Page and Fearn, 2005). Second, consumers are less willing to sacrifice basic functional features of products or services for CSR characteristics of the products (Auger et al., 2003; Becker-Olsen et al., 2006) and interestingly, a higher than average CSR (excessive giving) will negatively affect consumers' perceptions (Murray and Vogel, 1997). Most of these studies focus on consumer support for CSR in developed countries. In the same way that differences are found within the developed countries, consumers act differently in developing countries, especially when the characters of socio-economic consumers in this region are vastly different. These consumers have less financial capability to pay more for products with CSR content. Therefore, we propose the following hypothesis:

$\mathbf{H}_{3}$ : Consumers' perceptions of (a) economic, (b) legal, (c) ethical, and (d) philanthropic responsibilities will NOT affect consumers' support of CSR.

In the context of developed countries, studies show that background variables (age, gender, education, and position) are positively related to giving. Well-paid managers and professionals have a high propensity to donate. High-level givers in particular are found amongst people with higher incomes, job levels, and education (Haski-Leventhal, 2012; NCVO, 2008). Another study found that those within the age of 35-45 were most likely to donate (Romney-Alexander, 2001). Finally, gender differentials are apparent in all forms of 
charitable giving (Potter and Scales, 2008). As such, in the context of developing countries, this study derives the following hypothesis:

$\mathbf{H}_{4}$ : Consumers' support of CSR will differ based on (a) age, (b) gender, (c) education, and (d) position.

\section{The Research Context-Indonesia}

Indonesia is the fourth most populous nation in the world with around 240 million people and is the largest country in South East Asia (Population Reference Bureau, 2011). Indonesia is a country of cultural diversity and is home to the largest Muslim population in the world with $88 \%$ of the population being Muslim, followed by $8 \%$ Christian/Catholic, $2 \%$ Hindu, $1 \%$ Buddhist, and $1 \%$ other religions. The Indonesian economy is growing faster than other major emerging-market economies except for China with 6.5\% growth in 2011 (Reuters, 2012). The current Gross Domestic Product (GDP) per capita has grown to $\$ 3,542$ in 2012. Domestic consumption makes up more than 50\% of GDP, supported by a rising middle class and low interest rates (Kusuma and Rahadiana, 2012).

Despite its significant growth, Indonesia faces major challenges. Corruption, a lack of transparency, an inability to enforce contracts, cronyism, and nepotism are some of the major concerns of doing business in Indonesia. This has caused widespread cynicism and complicity in a culture used to official dishonesty, which does not bode well for CSR, which requires a high level of monitoring and transparency (Alatas, 1999; Kemp, 2001; Shauki, 2010). Transparency International ranks Indonesia $100^{\text {th }}$ in its annual survey of 183 countries. Recently, the World Bank (2012) ranked Indonesia $128^{\text {th }}$ out of 185 countries in its Annual Doing Business rankings. Indonesia is placed among the lowest in terms of starting a business (166th), resolving insolvencies (148th), getting electricity (147th), and enforcing contracts (144th). Indonesia also ranks poorly in terms of access to credit (129th) and paying taxes 
(131st). These are competing realities in Indonesia. Therefore, more studies are needed to explore consumers' perceptions of CSR in this nation.

\section{Methodology}

Instrument Development

The present study used existing scales developed by Maignan (2001). For consumer evaluation of corporate social responsibility, a total of sixteen items were employed - four for each social responsibility. Respondents were asked to rate each item on a five-point scale $(1=$ strongly disagree; 5 = strongly agree) based on a statement: "I believe a responsible business must..." (see Table 2). Furthermore, to measure consumer support of responsible businesses, respondents had to rate, on a five-point scale also developed by Maignan (2001) and modified by Ramasamy and Yeung (2008). The following statements are: (1) I would pay more to buy products from a socially responsible company; (2) I consider the ethical reputation of businesses when I shop; (3) I avoid buying products from companies that have engaged in immoral actions; (4) I would pay more to buy the products of a company that shows it cares for the well-being of our society; and (5) If the price and quality of two products are the same, I would buy from the firm that has a socially responsible reputation. Finally, demographic questions were also incorporated in the survey. Subsequently, an exploratory factor with Varimax rotation was conducted. All the items employed were translated into Indonesian and back translated to ensure the reliability of the scales.

\section{Data Collection and Respondent Demographics}

Using a convenience sample in Yogyakarta, Indonesia, 300 questionnaires were distributed in two areas: (1) in the food court area of a large shopping mall, and (2) in the canteen area and open space of a private university. The choice of convenience sampling in 
the food court area and a private university was due to their convenient accessibility and proximity to the researcher (Hair et al., 1995), as well as the purpose of having more diverse respondents in terms of age, education, and position. The non-probability method cause some members of the population have no chance of being included (Hair et al., 1995). Nonetheless, most population of people lives in Yogyakarta are Javanese ethnic group which represents $45 \%$ of Indonesia's total population (Levinson, 1998). Incomplete responses were removed, resulted in 254 usable surveys of respondents in Yogyakarta (a response rate of 84.7\%). Half of the respondents were male (53\%) and most of them were between 25 and 34 years old (64\%). Among them, $44 \%$ had high school education and $46 \%$ had a diploma/undergraduate education. In this survey, $48 \%$ of them were employees. Table 1 lists the detailed demographics of the respondents.

Insert Table 1 about Here

\section{Analysis and Results}

Consumer evaluation of CSR and CSR support were analysed through confirmatory factor analyses to assess and confirm the reliability of each multi scale items. The Principle Component Analysis (Varimax Rotation) was used to examine $\mathrm{H}_{1}$. Table 2 shows that four factors (i.e., one for each type of CSR) clearly emerged in the sample, except for "avoid compromising ethical standards in order to achieve corporate goals." Table 3 shows factor loadings and reliability of consumer support scale. Items with low communality $(<.5)$ or double loadings were removed. Communality and Eigenvalue indicators fell within recommended guidelines and Eigenvalue over one is considered acceptable (Hair et al., 1995). Thus, the results provided support for $\mathrm{H}_{1}$ [Consumers in Indonesia will distinguish between the following four types of corporate social responsibility: (a) economic, (b) legal, 
(c), ethical, and (d) philanthropic]. Respondents clearly appeared to regroup CSRs according to their economic, legal, ethical and philanthropic nature.

\section{Insert Table 2 and 3 about Here}

Hypothesis 2 was tested using a series of one-sample $t$-tests. Table 4 presents the correlations between each type of CSR and significant differences between them. It shows that no significant difference was found in the degree of importance allocated to legal and philanthropic responsibilities. Moreover, consumers in Indonesia rated philanthropic and legal responsibilities as significantly more importantly than economic and ethical responsibilities. Table 5 summarises the rankings of CSR and the significant differences. Indonesian consumers ranked the different social responsibilities in the following decreasing order: (1) philanthropic, (2) legal, (3) economic, and (4) ethical. Hence, the evidence that was gathered did not support $\mathrm{H}_{2}$.

\section{Insert Tables 4 and 5 about Here}

Similar to Maignan (2001) and Ramasamy and Yeung (2008), multiple regressions were used to examine $\mathrm{H}_{3}$ [Consumers' perceptions of (a) economic, (b) legal, (c) ethical, and (d) philanthropic responsibilities will NOT affect consumers' support of CSR]. Prior to performing regression analysis, the study produced the residual scatter plots to provide a visual examination of the assumptions of normality, linearity and homoscedasticity. The plot showed a random displacement of scores with no clustering or systematic pattern which indicated that the assumptions of normality, linearity and homoscedasticity were met (Hair et al, 1995). Subsequently, the regression results show that, the model was statistically significant (see Table 6) (the $F$ value was 17.049). The independent variables explain $26 \%$ of the variance in the dependent variable $\left(R^{2}=0.26\right)$. The legal $(\beta=0.27)$ and philanthropic $(\beta=$ 0.25) variables were statistically significant. Nevertheless, economic and ethical 
responsibilities were not statistically significant (see Table 7). Consequently, $\mathrm{H}_{3}$ was partially supported.

\section{Insert Tables 6 and 7 about Here}

Finally, $\mathrm{H}_{4}$ [Consumers' support of CSR will differ based on (a) age, (b) gender, (c) education, and (d) position] was investigated using an independent $t$-test for gender and an ANOVA for age, education, and profession. The present study did not find significant differences within the demographic factors (see Table 8).

Insert Table 8 about Here

\section{Discussions and Conclusions}

As indicated in the results of the factor analysis, like consumers in the developed countries (Maignan, 2001), consumers in Indonesia can distinguish between the four corporate social responsibilities - economic, legal, ethical, and philanthropic as defined by Carroll (1979). The findings revealed that each type of social responsibility as perceived by consumers in Indonesia stands on its own, not just one similar underlying construct. In addition, there are strong correlations between each of the responsibilities. Indonesian consumers consider all four types of responsibility as part of social responsibility. The results support the conceptualization by Maignan et al. (1999) who treated economic, legal, ethical, and philanthropic responsibilities as correlated dimensions.

Overall, the investigation confirms the applicability of Carroll's (1979) categorization of corporate social responsibilities to consumers in Indonesia but challenges the order of importance of these responsibilities as suggested by Visser (2008). In Indonesia, legal and philanthropic responsibilities get the most emphasis, followed by economic and ethical responsibilities. As previously discussed, in the last few decades, many companies in Indonesia have been perceived as supporters of corruption, nepotism, and collusion, which 
have caused many social and economic problems. Nevertheless, government efforts to curb corruption and improve the legal standards of doing business in Indonesia have shown progress (Wijayanto, 2011). Therefore, consumers show high expectations that companies will act within the standards defined by the law in order to minimize the negative social and economic consequences. Moreover, regarding philanthropic responsibility, most Indonesians are still constantly being battered by various social and economic issues. The findings suggest strong expectations from consumers that companies operating in Indonesia will improve the welfare of society through various philanthropic activities (donations, cause-related marketing, volunteering). Economic and ethical issues are considered less important by most consumers. Furthermore, regression results clearly indicated that perceptions toward legal and philanthropic responsibilities significantly explained consumers' support for responsible businesses. This shows that Indonesian consumers exhibit a high expectation of legal and philanthropic responsibilities in order to support companies' responsible businesses.

Therefore, it is important for businesses operating in Indonesia to focus on being companies that follow the regulatory system. Through CSR, companies can promote that their products or services are aligned with the laws and regulations thus met the required standards. This strategy will help increase companies' image as most local companies in Indonesia suffer from lack of trust due to rampant corruption and nepotism. Moreover, companies also need to support various philanthropic activities such as poverty reduction, especially when half of the population in Indonesia lives just above the national poverty line. By giving something back to society, through philanthropic activities, companies may gain trust from the community. It has been shown that an inoculation communication strategy will reduce perceived hypocrisy and mitigate its negative consequences (Wagner et al., 1999). To conclude, CSR does matter to consumers in Indonesia. 


\section{Limitations and Future Research}

Limitations are inevitable in any convenience sampling. The sample was taken from one city (i.e. Yogyakarta) in Indonesia. Despite Yogyakarta is the Indonesia's second most popular tourist destination after Bali and "a microcosm of Indonesia" (Susanto, 2013, p. 9), it may not represent all Indonesia. It might be reflected in the low Cronbach Alpha for ECO and ETH. Thus, the scale requires further development in the future. Consequently, this limits the generalizability of the findings. Future research should attempt to obtain data from other cities in Indonesia. In addition, we do not have information on the income level of the respondents, which might affect their perceptions of companies. Moreover, a social desirability bias may have been a factor in response to some of the questions. Respondents in Indonesia may have provided a socially desirable response to appear ethical (Al-Khatib et al., 2005; Lu and Lu, 2009). Finally, we do not differentiate between perceptions of local and multinational corporations. This might have an effect, as overseas companies are seen favourably by consumers in Indonesia. Future research may investigate this issue. Nevertheless, this study may benefit managers operating in Indonesia when they want to promote their CSR activities. As Mohr et al. (2001) suggest, an understanding of consumer expectation of CSR at the firm level is critical in the development and implementation of successful CSR programs. 


\section{References}

Alatas, S.H. (1999), Corruption and the Destiny of Asia, Prentice Hall, Kuala Lumpur, Malaysia.

Al-Khatib, J.A., Stanton, A.D. and Rawwas, M.Y.A. (2005), "Ethical segmentation of consumers in developing countries: A comparative analysis", International Marketing Review, Vol. 22 No. 2, pp. 225-46.

Ameshi, K., Adi, B., Ogbechie, C. and Amao, O. (2006), "Corporate social responsibility in Nigeria: Western mimicry or indigenous influences", Journal of Corporate Citizenship, Vol. 24, pp. 83-99.

Arli, D. and Lasmono, H. (2010), "Consumers' perception of corporate social responsibility in a developing country", International Journal of Consumer Studies, Vol.34, No. 1, pp. 4651 .

Auger, P., Burke, P., Devinney, T.M. and Louviere, J.J. (2003), "What will consumers pay for social product features?", Journal of Business Ethics, Vol. 42 No. 3, pp. 281-304.

Baskin, J. (2006), "Corporate responsibility in emerging markets", Journal of Corporate Citizenship, Vol. 24 Winter Issue, pp. 29-47.

Becker-Olsen, K.L., Cudmore, B.A. and Hill, R.P. (2006), "The impact of perceived corporate social responsibility on consumer behaviour", Journal of Business Research, Vol. 59, pp. 46-53.

Brown, T. and Dacin, P.A. (1997), "The company and the product: Corporate associations and consumer product responses", Journal of Marketing, Vol. 61 No. 1, pp. 68-84.

Bucic, T., Harris, J. and Arli, D. (2012), "Ethical consumers among the Millennials: A crossnational study", Journal of Business Ethics, Vol. 110, No. 1, pp. 113-31.

Burton, B.K., Farh, J.-L. and Hegarty, W.H. (2000), "Across-cultural comparison of corporate social responsibility orientation: Hong Kong vs. United States students", Teaching Business Ethics, Vol. 4 No. 2, pp. 151-67.

Campbell, L.J. (2007), "Why should corporations behave in socially responsible ways? An institutional theory of corporate social responsibility", Academy of Management Review, Vol. 32 No. 3, pp. 946-67.

Carroll, A.B. (1979), "A three-dimensional conceptual model of corporate performance", Academy of Management Review, Vol. 4 No. 4, pp. 497-505.

Carroll, A.B. (1991), "The pyramid of corporate social responsibility: Toward the moral management of organizational stakeholders", Business Horizons, Vol. 34 No. 4, pp. 39-48.

Carroll, A.B. (1999), "Corporate social responsibility: Evolution of a definitional construct", Business and Society, Vol. 38 No. 3, pp. 268-95. 
Carroll, A.B. (2004), "Managing ethically with global stakeholders: A present and future challenge", Academy of Management Executive, Vol. 18 No. 2, pp. 114-19.

Coombs, W.T. (1995), "Choosing the right words: The development of guidelines for the selection of 'appropriate' crisis-response strategies", Management Communication Quarterly, Vol. 8 No. 2, pp. 279-95.

Cretu, A.E. and Brodie, R.J. (2007), "The influence of brand image and company reputation where manufacturers marketing to small firms: A customer value perspective", Industrial Marketing Management, Vol. 36 No. 2, pp. 230-40.

Creyer, E.H. and Ross, W.T. (1997), "The influence of firm behaviour on purchase intention: Do consumers really care about business ethics", Journal of Consumer Marketing, Vol. 14 No. 6, pp. 421-32.

Dawkins, J. and Lewis, S. (2003), "CSR in stakeholder expectations: and their implications for company strategy, Journal of Business Ethics, Vol. 28 No. 3, pp. 291-313.

Dean, D.H. (2004), "Consumer reaction to negative publicity: Effects of corporate reputation, response, and responsibility for a crisis event", Journal of Business Communication, Vol. 41 No. 2, pp. 192-211.

Fombrum, C., Gardberg, N. and Barnett, M. (2000), "Opportunity platforms and safety nets: Corporate citizenship and reputation risks", Business and Society Review, Vol. 105 No. 1, pp. 85-106.

Forbes (2012), "Top 3 countries to invest in next 3 years, according to the UN", available at: http://www.forbes.com/sites/kenrapoza/2012/07/05/top-3-countries-to-invest-in-next-3-yearsaccording-to-the-u-n/ (accessed 23 January 2013).

Freeman, R.E. (1984), Strategic Management: A Stakeholder Approach, Pitman, Boston, MA.

Hair, J.F., Jr., Anderson, R.E., Tatham, R.L. and Black, C. (1995), Multivariate Data Analysis with Readings, Third Edition, MacMillan, New York, NY.

Haski-Leventhal, D. (2012), "Employee engagement in CSR: The case of payroll giving in Australia", Corporate Social Responsibility and Environmental Management. DOI:10.1002/csr.1287.

Jamali, D. (2008), "A stakeholder approach to corporate social responsibility: A fresh perspective into theory and practice", Journal of Business Ethics, Vol. 82 No. 1, pp. 213-31.

Jones, R. (2005), "Finding sources of brand value: Developing a stakeholder model of brand equity", Brand Management, Vol. 13 No. 1, pp. 10-32.

Jones, B., Bowd, R. and Tench, R. (2009), "Corporate irresponsibility and corporate social responsibility: Competing realities”, Social Responsibility Journal, Vol. 5 No. 3, pp. 300-10. 
Kemp, M. (2001), "Corporate social responsibility in Indonesia: Quixotic dream or confident expectation?", United Nations Research Institute for Social Development (UNRISD), available

from:

http://www.unrisd.org/80256B3C005BCCF9/(httpAuxPages)/EF8F86E50D18E6D480256B6 1005AE53A/\$file/kemp.pdf (accessed 11 January 2013).

Kotler, P. and Lee, N. (2005). Corporate Social Responsibility: Doing the Most Good for Your Company and Your Cause, Wiley, Hoboken, NJ.

Kusuma, A.N. and Rahadiana, R. (2012), "Direct investment pours into Indonesia despite worries", available from: http://www.reuters.com/article/2012/10/22/us-indonesia-economyfdi-idUSBRE89L04220121022 (accessed 12 January 2013).

Lai, C.S., Chie, C.-J., Yang, C.-F. and Pai, D.-C. (2010), "The effects of corporate social responsibility on brand performance: Mediating effect of industrial brand equity and corporate reputation", Journal of Business Ethics, Vol. 95 No. 3, pp. 457-69.

Lindgreen, A., Swaen, V. and Campbell, T.T.(2010), "Corporate social responsibility practices in developing and transitional countries: Botswana and Malawi", Journal of Business Ethics, Vol. 90 No. 3, pp. 429-440.

Lu, L.-J. and Lu, C.-J. (2009), "Moral philosophy, materialism and consumer ethics: An exploratory study in Indonesia", Journal of Business Ethics, Vol. 94 No. 2, pp. 193-210.

Maignan, I. (2001), "Consumers' perceptions of corporate social responsibilities: A cross cultural comparison”, Journal of Business Ethics, Vol. 30 No. 1, pp. 57-72.

Maignan, I., Ferrell, O.C. and Hult, T.G. (1999), "Corporate citizenship: Cultural antecedents and business benefits", Journal of the Academy of Marketing Science, Vol. 27 No. 4, pp. 45569.

Marconi, J. (1997), Crisis Marketing: When Bad Things Happen to Good Companies, Chicago: American Marketing Association.

Margolis, J.D., Elfenbein, H.A. and Walsh, J.P. (2008), "Do well by doing good? Count on it", Harvard Business Review, Vol. 86 No. 1, pp. 19-20.

McDonald, L.M. and Rundle-Thiele, S. (2008), "Corporate social responsibility and bank customers' satisfaction: A research agenda", International Journal of Bank Marketing, Vol. 26 No. 3, pp. 170-82.

McKinsey (2010), "How companies manage sustainability: McKinsey global survey results", available at https://www.mckinseyquarterly.com/ (accessed 31 March, 2010).

McWilliams, A., Siegel, D.S. and Wright, M. (2006), "Corporate social responsibility: Strategic implications", Journal of Management Studies, Vol. 43 No. 1, pp. 1-18.

Mohr, L.A. and Webb, D.J. (2005), "The effects of corporate social responsibility and price on consumer responses", Journal of Consumer Affairs, Vol. 39 No. 1, pp. 121-47. 
Mohr, L.A., Webb, D.J. and Harris, K.E. (2001), "Do consumers expect companies to be socially responsible? The impact of corporate social responsibility on buying behaviour", Journal of Consumer Affairs, Vol. 35 No. 1, pp. 45-72.

Mudambi, S.M. (2002), "Branding importance in business-to-business markets: Three buyer clusters", Industrial Marketing Management, Vol. 43 No. 6, pp. 525-33.

Murray, K.B. and Vogel, C.M. (1997), "Using a hierarchy-of-effects approach to gauge the effectiveness of corporate social responsibility to generate goodwill toward the firm: Financial versus non-financial impacts", Journal of Business Research, Vol. 38 No. 2, pp. 141-60.

NCVO. (2008), "UK giving 2008: An overview of charitable giving in the UK, 2007/08", National Council for Voluntary Organizations, London.

Page, G. and Fearn, H. (2005), "Corporate reputation: What do consumers really care about", Journal of Advertising Research, Vol. 45 No. 3, pp. 305-11.

Pinkston, T.S. and Carroll, A.B. (1994), "Corporate citizenship perspective and foreign direct investment in the U.S.”, Journal of Business Ethics, Vol. 13 No. 3, pp. 157-69.

Podnar, K. and Golob, U. (2007), "CSR expectations: The focus of corporate marketing", Corporate Communications: An International Journal, Vol. 12 No. 4, pp. 326-40.

Population Reference Bureau (2011), "The world at 7 billion: World population data sheet 2011", available from: http://www.prb.org/Publications/Datasheets/2011/world-populationdata-sheet/data-sheet (accessed 11 January 2013).

Potter, V. and Scales, J. (2008), "Review of payroll giving”, Strategy Complete, London.

Quazi, A. and O'Brien, D. (2000), "An empirical test of across-national model of corporate social responsibility”, Journal of Business Ethics, Vol. 25 No. 1, pp. 33-51.

Ramasamy, B. and Yeung, M. (2008), "Chinese consumers' perception of corporate social responsibility", Journal of Business Ethics, Vol. 88 No. 1, pp. 119-32.

Ramasamy, B., Yeung, M.C.H. and Au, A.K.M. (2010), "Consumer support for corporate social responsibility (CSR): The role of religion and values", Journal of Business Ethics, Vol. 91 No. 1, pp. 61-72.

Reuters (2012), "Indonesia surprise with surge in economy", available from: http://www.nytimes.com/2012/08/07/business/global/indonesia-surprises-with-surge-ineconomy.html?_r=0 (accessed 10 January 2013).

Romney-Alexander, D. (2001), "Payroll giving in the UK: Donor incentives and influences on giving behaviour", International Journal of Nonprofit and Voluntary Sector Marketing, Vol. 7 No. 1, pp. 84-92. 
Sen, S. and Bhattacharya, C.B. (2001), "Does doing good always lead to doing better? Consumer reactions to corporate social responsibility", Journal of Marketing Research, Vol. 38 No. 2, pp. 225-43.

Shauki, E. (2010), "Perceptions on corporate social responsibility: A study in capturing public confidence", Corporate Social Responsibility Environment Management, Vol. 18 No. 3, pp. 200-08.

Shergill, S.S. (2012), "Consumer perception towards the corporate social responsibility: A case study of India", European Journal of Business and Management, Vol. 4 No. 4, pp. 4757.

Smith, N.C., Read, D. and Lopez-Rodriguez, S. (2010), "Consumer perceptions of corporate social responsibility: The CSR halo effect", Faculty \& Research Working Paper, INSEAD, available from: http://www.insead.edu/facultyresearch/research/doc.cfm?did=43990 (accessed 20 January 2013).

Smith, W. and Higgins, M. (2000), "Cause-related marketing: Ethics and the ecstatic", Business and Society, Vol. 39 No. 3, pp. 304-22.

Susanto, S. (2013), "Premanisme', a root cause for violence in Yogyakarta", Jakarta Post, April 11, p. 9.

Tsoi, J. (2010), "Stakeholders' perception and future scenarios to improve corporate social responsibility in Hong Kong and Mainland China", Journal of Business Ethics, Vol. 91 No. 3, pp. 391-404.

Turker, D. (2008), "How corporate social responsibility influences organizational commitment", Journal of Business Ethics, Vol. 89 No. 2, pp. 189-204.

Vanhamme, J. and Grobben, B. (2009), “'Too good to be true': The effectiveness of CSR history in countering negativity publicity", Journal of Business Ethics, Vol. 85 No. 2, pp.27383.

Varadarajan, P.R. and Menon, A. (1988), "Cause-related marketing: A coalignment of marketing strategy and corporate philanthropy", Journal of Marketing, Vol. 52 No. 3, pp. 5874.

Visser, W. (2006), "Revisiting Carroll's CSR pyramid: An African perspective", in E.R. Pedesen and M. Huniche (eds.), Corporate Citizenship in Developing Countries, Copenhagen Business School Press, Copenhagen, pp. 29-48.

Visser, W. (2008), "Corporate social responsibility in developing countries", in A. Crane, A. McWilliams, D. Matten, J. Moon and D. Siegel (eds.), The Oxford Handbook of Corporate Social Responsibility, Oxford University Press, Oxford, pp. 473-79.

Wagner, T., Lutz, J. and Weitz, B.A. (1999), "Corporate hypocrisy: Overcoming the threat of inconsistent corporate social responsibility perceptions", Journal of Marketing, Vol. 73 No. 6, pp. 77-91. 
Wijayanto (2011), "The truth about corruption in Indonesia", available from: http://www.thejakartaglobe.com/columnists/the-truth-about-corruption-in-indonesia/456342 (accessed 23 January 2012).

World Bank (2012), "Doing business: Measuring business regulations", available from: http://www.doingbusiness.org/rankings (accessed 11 January 2013). 
Table 1. Profile of respondents

\begin{tabular}{|l|l|c|}
\hline Demographic & Percentage \\
\hline \multirow{4}{*}{ Age } & $18-24$ years old & $8 \%$ \\
\cline { 2 - 3 } & $25-34$ years old & $64 \%$ \\
\cline { 2 - 3 } & 35-44 years old & $20 \%$ \\
\cline { 2 - 3 } & 45-54 years old & $6 \%$ \\
\cline { 2 - 3 } & 55 and above & $2 \%$ \\
\hline \multirow{5}{*}{ Education } & Male & $53 \%$ \\
\cline { 2 - 3 } & Female & $47 \%$ \\
\cline { 2 - 3 } & High School & $44 \%$ \\
\cline { 2 - 3 } & Diploma/Undergraduate & $46 \%$ \\
\cline { 2 - 3 } & Postgraduate & $10 \%$ \\
\cline { 2 - 3 } & Managers & $8 \%$ \\
\cline { 2 - 3 } & Employees & $13 \%$ \\
\cline { 2 - 3 } & Entrepreneurs & $6 \%$ \\
\cline { 2 - 3 } & Teachers and Lecturers & $8 \%$ \\
\cline { 2 - 3 } & Students & \\
\cline { 2 - 3 } & Others (Retired and Housewives) & $17 \%$ \\
\hline
\end{tabular}

Table $2^{\text {a }}$. Scale items and exploratory factor analysis of corporate social responsibility

\begin{tabular}{|c|c|c|c|c|c|}
\hline \multirow[t]{2}{*}{ I believe that a responsible business must: } & \multicolumn{4}{|c|}{ Factor loadings ${ }^{b}$} & \multirow[b]{2}{*}{ Cty $^{\mathrm{c}}$} \\
\hline & LEG & PHI & ECO & ETH & \\
\hline Control their production cost strictly & .108 & .253 & .744 & -.020 & 0.63 \\
\hline Plan for their long-term success & .330 & -.032 & .656 & .018 & 0.54 \\
\hline Always improve economic performance & .374 & .109 & .649 & -.031 & 0.57 \\
\hline Maximize profits & -.034 & -.238 & .554 & .333 & 0.48 \\
\hline $\begin{array}{l}\text { Ensure that their employees act within the } \\
\text { standards defined by law }\end{array}$ & .709 & .154 & .192 & -.100 & 0.57 \\
\hline $\begin{array}{l}\text { Refrain from putting aside their contractual } \\
\text { obligations }\end{array}$ & .567 & .165 & .383 & .025 & 0.50 \\
\hline $\begin{array}{l}\text { Refrain from bending the law even if this helps } \\
\text { improve performance }\end{array}$ & .694 & .009 & .111 & .087 & 0.50 \\
\hline $\begin{array}{l}\text { Always submit to the principles defined by the } \\
\text { regulatory system }\end{array}$ & .664 & .090 & .156 & .263 & 0.54 \\
\hline $\begin{array}{l}\text { Permit ethical concerns to negatively effect } \\
\text { economic performance }\end{array}$ & .597 & .229 & .151 & .048 & 0.43 \\
\hline $\begin{array}{l}\text { Ensure that the respect of ethical principles has } \\
\text { priority over that of economic performance }\end{array}$ & .017 & .243 & .064 & .699 & 0.55 \\
\hline Be committed to well-defined ethics Principles & .491 & .078 & -.041 & .622 & 0.64 \\
\hline $\begin{array}{l}\text { Avoid compromising ethical standards in order } \\
\text { to achieve corporate goals }\end{array}$ & .379 & .185 & .061 & .272 & 0.26 \\
\hline Help solve social problems & .038 & .758 & .088 & .274 & 0.66 \\
\hline Participate in the management of public affairs & .043 & .710 & .182 & .300 & 0.63 \\
\hline $\begin{array}{l}\text { Allocate some of their resources to } \\
\text { philanthropic activities }\end{array}$ & .235 & .749 & .062 & -.002 & 0.62 \\
\hline $\begin{array}{l}\text { Play a role in our society that goes beyond the } \\
\text { mere generation of profits }\end{array}$ & .334 & .602 & -.167 & -.072 & 0.50 \\
\hline Eigenvalue & 4.53 & 1.86 & 1.20 & 1.03 & \\
\hline Cronbach alpha & 0.76 & 0.74 & 0.58 & 0.40 & \\
\hline
\end{tabular}

Note: ${ }^{a}$ ECO $=$ economic responsibility, LEG $=$ legal responsibility, ETH $=$ ethical responsibility, PHI $=$ philanthropic responsibilities; ${ }^{\mathrm{b}}$ a Varimax rotation was employed; cty = communality estimates; represent the squared multiple correlations for predicting the estimated factors.

Table 3. Scale items of consumer support

\begin{tabular}{|l|l|l|}
\hline Item & Factor loading $^{\text {b }}$ & cty \\
\hline
\end{tabular}




\begin{tabular}{|l|l|l|}
\hline $\begin{array}{l}\text { I would pay more to buy products from a } \\
\text { socially responsible company. }\end{array}$ & $\mathbf{. 7 2 5}$ & 0.52 \\
\hline $\begin{array}{l}\text { I avoid buying products from companies that } \\
\text { have engaged in immoral actions. }\end{array}$ & $\mathbf{. 5 8 3}$ & 0.34 \\
\hline $\begin{array}{l}\text { I consider the ethical reputation of business } \\
\text { when I shop. }\end{array}$ & $\mathbf{. 5 8 0}$ & 0.33 \\
\hline $\begin{array}{l}\text { I would pay more to buy products from } \\
\text { companies that show care for the well-being of } \\
\text { our society. }\end{array}$ & $\mathbf{. 7 3 6}$ & 0.54 \\
\hline $\begin{array}{l}\text { If the price and quality of two products are the } \\
\text { same, I would buy from a firm that has a } \\
\text { socially responsible reputation. }\end{array}$ & $\mathbf{. 7 0 2}$ & 0.49 \\
\hline $\begin{array}{l}\text { Eigenvalue } \\
\text { Cronbach alpha }\end{array}$ & 2.23 & \\
\hline
\end{tabular}

Note: ${ }^{b}$ a Varimax rotation was employed; cty = communality estimates; represent the squared multiple correlations for predicting the estimated factors.

Table 4. Social responsibilities: Correlations, differences ( $t$-tests), and mean $\mathrm{s}^{\mathrm{a}}$

\begin{tabular}{|l|l|l|l|l|l|}
\hline & LEG & PHI & ECO & ETH & CSR \\
\hline LEG & 1 & $0.38^{* *}$ & $0.44^{* *}$ & $0.38^{* *}$ & $0.39^{* *}$ \\
\hline PHI & $-0.66^{* *}$ & 1 & $.138^{*}$ & $.364^{* *}$ & $0.36^{* *}$ \\
\hline ECO & $3.00^{* *}$ & $2.98^{*}$ & 1 & $.172^{* *}$ & $0.23^{* *}$ \\
\hline ETH & $10.73^{* *}$ & $11.35^{* *}$ & $7.33^{*}$ & 1 & $0.25^{* *}$ \\
\hline CSR & $11.18^{* *}$ & $11.47^{* *}$ & $7.55^{* *}$ & $-0.46^{* *}$ & 1 \\
\hline & & & & & \\
\hline MEAN & 4.28 & 4.30 & 4.17 & 3.83 & 3.85 \\
\hline
\end{tabular}

Note: ${ }^{a}$ Above the diagonal, Pearson' correlations; below the diagonal, $t$-values in italic; $* * p<0.01, * p<0.05$; CSR $=$ Corporate Social Responsibility Support.

Table 5. Rankings and differences

\begin{tabular}{|l|l|l|}
\hline & Mean (Ranking) & Significantly different from \\
\hline PHI & $4.30(1)$ & ECO, ETH \\
\hline LEG & $4.28(2)$ & ECO, ETH \\
\hline ECO & $4.17(3)$ & LEG, PHI, ETH \\
\hline ETH & $3.83(4)$ & LEG, ECO, ETH \\
\hline
\end{tabular}

Table 6. Model summary

\begin{tabular}{|l|l|l|}
\hline Dependent & $\boldsymbol{R}^{2}$ & F Value \\
\hline Consumer Support & 0.26 & $17.049^{* *}$ \\
\hline
\end{tabular}

Table 7. Determinants of consumer support toward CSR

\begin{tabular}{|l|l|l|l|l|l|}
\hline Model & Unstandardized Coefficients & \multicolumn{2}{l|}{ Standardized Coefficients } & \\
\hline & $\boldsymbol{\beta}$ & Std.Error & $\boldsymbol{\beta}$ & $\mathbf{t}$ & Sig. \\
\hline (Constant) & 1.03 & 0.36 & & 2.83 & $\mathbf{0 . 0 0}$ \\
\hline LEG & 0.27 & 0.08 & 0.25 & 3.62 & $\mathbf{0 . 0 0}$ \\
\hline PHI & 0.25 & 0.07 & 0.23 & 3.64 & $\mathbf{0 . 0 0}$ \\
\hline ECO & 0.09 & 0.07 & 0.08 & 1.22 & 0.22 \\
\hline ETH & 0.06 & 0.06 & 0.07 & 1.08 & 0.18 \\
\hline
\end{tabular}

Table 8. Consumer support for CSR 


\begin{tabular}{|c|c|c|c|c|}
\hline \multicolumn{2}{|c|}{ Demographic $(\mathrm{N}=254)$} & Means & F value & Sig. \\
\hline \multirow[t]{5}{*}{ Age } & $18-24$ years old & 4.03 & \multirow{5}{*}{1.03} & \multirow{5}{*}{0.39} \\
\hline & 25-34 years old & 3.80 & & \\
\hline & $34-44$ years old & 3.88 & & \\
\hline & 45-54 years old & 3.93 & & \\
\hline & 55 and above & 4.08 & & \\
\hline \multirow[t]{2}{*}{ Gender } & Male & 3.89 & \multirow{2}{*}{1.60} & \multirow{2}{*}{0.20} \\
\hline & Female & 3.80 & & \\
\hline \multirow[t]{3}{*}{ Education } & High School & 3.83 & \multirow{3}{*}{0.29} & \multirow{3}{*}{0.75} \\
\hline & Diploma/Undergraduate & 3.86 & & \\
\hline & Postgraduate & 3.92 & & \\
\hline \multirow[t]{6}{*}{ Position } & Managers & 3.94 & \multirow{6}{*}{0.68} & \multirow{6}{*}{0.64} \\
\hline & Employees & 3.81 & & \\
\hline & Entrepreneurs & 3.81 & & \\
\hline & Teachers and Lecturers & 3.76 & & \\
\hline & Students & 3.90 & & \\
\hline & Others (Retired and Housewives) & 3.85 & & \\
\hline
\end{tabular}


Denni Arli is currently a Lecturer at the Department of Marketing, Griffith Business School, Griffith University, Australia. His research interests include corporate social responsibility, consumer ethics, social marketing and the impact of religiosity on consumption. He has co-authored articles published or forthcoming at the Journal of Business Ethics, Social Responsibility Journal, Journal of Asia-Pacific Business and International Journal of Consumer Studies.

Fandy Tjiptono is currently a Senior Lecturer at the Management Department, Universitas Atma Jaya Yogyakarta, Indonesia. His research interests include corporate social responsibility, consumer ethics, brand longevity, and marketing in developing countries. 